Szegedi Tudományegyetem Fogorvostudományi Kar Parodontológiai Tanszék* Szegedi Tudományegyetem Fogorvostudományi Kar Fogpótlástani Tanszék** Szegedi Tudományegyetem Általános Orvostudományi Kar Tüdőgyógyászati Tanszék ${ }^{\star \star \star}$

Szegedi Tudományegyetem Fogorvostudományi Kar V. évfolyamos hallgató ${ }^{\star \star \star \star ~}$

\title{
A fogágybetegség és a krónikus obstruktív tüdőbetegség kapcsolatának jelentősége
}

\author{
Irodalmi összefoglaló
}

DR. TIÁN TAMÁS*, DR. GORZÓ ISTVÁN*, ŐSZE GÁBOR ${ }^{\star \star \star \star}$, DR. SOMFAY ATTILA**, DR. RADNAI MÁRTA**

\begin{abstract}
A fogágybetegség és a krónikus obstruktív tüdőbetegség (COPD) is a leggyakrabban megjelenő krónikus betegségek csoportjába tartozik. A fogelvesztéssel járó előrehaladott fogágybetegség a világ 6 . leggyakrabban előforduló krónikus betegsége, mely kb. 743 millió embert érint, míg a COPD világszerte évente átlagosan 3 millió emberéletet követel (ez 5,3\%-a az összes haláloknak világszerte) és 2016 óta a világ 3. vezető halálokává vált. Egy norvég tanulmány szerint a nagyon súlyos COPD-ben szenvedő, tüdőtranszplantáció előtt álló betegek esetén a parodontitisz prevalenciája megközelíti a 44\%-ot, szemben a nem COPD-s kontrollcsoport 7,3\%-os gyakoriságával. A két betegség összefüggése jelenleg direkt módon nem bizonyított, ám egyre több tanulmány támasztja alá a két betegség közti kapcsolat lehetőségét. Tanulmányunkban összegezni szeretnénk a jelenleg elérhető szakirodalmi adatokat és ez által betekintést nyújtani a két betegség kölcsönhatásába és feltételezett patomechanizmusába. Szükség lenne olyan klinikai vizsgálatokra, melyekben nagy esetszámmal vizsgálnak parodontálisan érintett COPD-s betegeket, így megerősítve vagy cáfolva azt a feltevést, miszerint a fogágybetegek parodontális terápiája hozzájárulhat-e a COPD-ben szenvedő betegek életminőségének javításához.
\end{abstract}

Kulcsszavak: krónikus obstruktív tűdőbetegség, COPD, parodontitisz, patomechanizmus, prevalencia

\section{Bevezetés}

A fogelvesztéssel járó előrehaladott fogágybetegség a világ 6 . leggyakrabban előforduló krónikus betegsége, mely kb. 743 millió embert érint (11,2\%) [26]. A fogágybetegség a fog rögzítő apparátusának irreverzibilis károsodásával járó krónikus gyulladása, ahol a gingivális szulkuszban a parodontopatogén mikroflóra javára bakteriális eltolódás következményeként alakul ki a szervezet válaszreakciója [51]. Magyarországon utoljára 2009-ben végeztek teljes országot lefedő epidemiológiai vizsgálatot fogyágybetegség prevalenciával kapcsolatban. A klinikai állapotokat az Egészségügyi Világszervezet (WHO) által bevezetett, nagy populációk szürésére alkalmas, Community Periodontal Index (CPI-index) alapján rangsorolták [36]. A vizsgált populáció csupán $12 \%$-ánál volt $\mathrm{CPI}-0$ az érték, azaz klinikailag teljesen egészséges a fogágy. A CPI-1 megoszlása $8 \%$ volt, vagyis csak ínyvérzés volt jelen parodontális szondázást követően, míg CPI-2 a populáció $49 \%$-ánál fordult elö. CPI-2 esetén szondázást követően ínyvérzés jelent meg és fogkő is észlelhető volt. Mérsékelt parodontitisz esetén a 4-5 mm-es tasakmélység (CPI-3) a populáció $23 \%$-ánál, míg súlyos parodontitisz, tehát 5,5 mm-es tasakmélységnél magasabb érték (CPI-4) a populáció $7 \%$-ánál volt jelen. A férfiak esetében $34 \%$, a nők esetén $28 \%$-nál fordult elő a CPI-2-nél magasabb érték. Korcsoportok alapján a CPI-2 vagy annál magasabb érték a 45 évnél idősebb lakosságot érinti nagyobb mértékben [14].

\section{Fogágybetegség és a szisztémás betegségek kapcsolata}

A fogágybetegséggel összefüggésbe hoztak olyan betegségeket és állapotokat, mint a szív- és érrendszeri megbetegedések csoportja [9], a diabétesz mellitusz [44], a reumathoid arthritis [3], gyomorfekély [4], a terhesség szővődményei [35], valamint a légzőszervrendszeri megbetegedések közül az aspirációs pneumonia és a krónikus obstruktív tüdőbetegség (chronic obstructive pulmonary disease, COPD) [16]. Számos tanulmány bizonyította indirekt módon a fogágybetegség és a COPD összefüggését, habár a pontos patomechanizmus a mai napig nem tisztázott [52]. 


\section{A COPD gyakorisága, jellemzői és ismert kockázati tényezői}

A COPD gyulladásos eredetű, megelőzhető kórkép, melyet progresszív bronchiális obstrukció jellemez [5]. Definíció szerint akkor bizonyított a tüdőbetegség fennállása, ha hörgőtágító aeroszol inhalációja után mérve az eröltetett kilégzési másodperctérfogat (forced expiratory volume in one second, FEV1) és erőltetett kilégzési vitálkapacitás (forced vital capacity, FVC) aránya kisebb mint 0,7, valamint a FEV1 értéke alacsonyabb, mint a referencia-érték $80 \%$-a [22]. A COPD világszerte évente átlagosan 3 millió emberéletet követel (ez 5,3\%a az összes haláloknak világszerte) és 2016 óta a világ 3. vezető halálokává vált [24]. A COPD prevalenciája a 40 évnél idősebb korú lakosság körében 9-10\%-ra tehető és világszerte közegészségügyi problémát okoz magas előfordulási és halálozási aránya miatt [49]. Az európai férfiak tekintetében a halálozási arányok a legtöbb országban csökkenő tendenciát mutatnak, ám Magyarországon ez az érték 2005 óta változatlan [29]. Világviszonylatban 2016 és 2018 között COPD következtében a legmagasabb halálozási arány a férfiak körében Magyarországon és Kirgizisztán területén volt, ami átlagosan 141 és 135 haláleset/100 000 fö/évet jelent. A nők esetében, világviszonylatban a COPD és szövődményei miatt bekövetkező halálesetek száma az Egyesült Államokban és Magyarországon a legmagasabb, mely átlagosan 75 , illetve 71 haláleset/100000 fó lévet jelent [29]. Továbbá fontos, hogy a COPD és következményei miatt bekövetkező halálozási arány emelkedik Európa-szerte, Ausztriában évente 2\%-kal, Csehországban 4,2\%-kal és Magyarországon 4,8\%kal [29]. Magyarországon 2000-ben 48000 [5], 2013ban 174949 [5], míg 2015-ben 183800 COPD-s beteget regisztráltak a tüdőgyógyászati adatbázisban [23]. A COPD-s betegek valós száma a becslések alapján akár az 500000 fôt is elérheti [5]. A betegség aluldiagnosztizáltságának feltételezett okai között szerepel az alapellátásban kapott tüneti szerek alkalmazása, valamint hogy a COPD gyakran második és harmadik diagnózisként jelenik meg, így a betegeket kardiovaszkuláris, anyagcsere és mozgásszervi megbetegedésekkel gondozzák elsősorban [5].

A klasszikus kockázati tényezők, mint például a genetikai tényezők, a dohányzás, a szennyezett levegő, a munkahelyi por és a vegyianyag-ártalom jelentősen befolyásolják a COPD kialakulását [49]. Egy metaanalízis arra a következtetésre jutott, hogy a COVID-19 fertőzöttség rontja a COPD-ben szenvedő betegek túlélési esélyeit, csakúgy, mint az aktív dohányzás [1]. Becslések szerint a krónikus dohányzók 15-20\%-ánál alakul ki COPD és a betegek $80-90 \%$-a régebben dohányzott vagy jelenleg is dohányzik. A dohányzás világviszonylatban Európában a legelterjedtebb. A közép- és keleteurópai országokban a népesség $30 \%$-át meghaladó dohányzási gyakoriság figyelhető meg. A dohányzás az európai férfiak körében 2000 és 2015 között csökkenő tendenciát mutatott. A csökkenés medián értéke 1,5\% lév, habár a megoszlás országonként szignifikánsan eltérő (Ausztriában szignifikáns prevalencia csökkenés tapasztalható, míg Kirgizisztán területén jelenleg is tovább emelkedik a dohányosok száma). Azokban az országokban, melyek 2004 után csatlakoztak az Európai Unióhoz (EU13), a nők átlagosan többet dohányoznak, mint a Független Államok Közössége (FÁK) országaiban. Ebből következik, hogy a férfiak és a nők dohányzási szokásai közötti különbség az EU13 országaiban kevésbé markáns (például Horvátországban a férfiak 37,9\%, a nők 28,9\%-a dohányzott 2015-ben) [18].

Magyarországon 2012 [19] és 2013 [20] között a dohányzók prevalenciája csökkenő tendenciát mutatott. Egy 2012-es felmérés alapján a nem dohányzók aránya $55 \%$, a dohányzók aránya $29 \%$, míg a leszokottak aránya $16 \%$ volt a vizsgálati populációban. A 2013-ban kapott eredmények szerint a nem dohányzók aránya $57 \%$, a dohányzóké $21 \%$, míg a leszokottak aránya $22 \%$ volt. A nemi különbségeket vizsgálva elmondható, hogy a nők 24\%-a, a férfiak 32\%-a napi rendszerességgel dohányzott a 2012-es felmérés alapján. 2013-ban ugyanez az adat a férfiak esetében 23\%-ra, nők esetében 15\%-ra csökkent. Ami az életkori megoszlásokat illeti, 2012-ben a naponta dohányzók zöme $(32,4 \%)$ középkorú, azaz 35-64 év közötti, míg további 30\%-uk 18 és 24 év közötti fiatal felnőtt volt [21].

A légszennyezés, valamint a munkahelyi por és vegyi ártalom alacsony számú megbetegedésért szintén felelőssé tehető [45].

A COPD patogenezise során a belélegzett káros gázok (pl. dohányfüst) gyulladásos kaszkádot indítanak el a légzőrendszerben. A kaszkád túlmüködése a tüdő kötőszövetének pusztulását (emfizéma), a szövetek regenerációs funkciójának meghibásodását, kislégúti fibrózist és annak következményeként bronchiális obstrukciót eredményez [5]. A COPD-s betegek 97\%-a szenved legalább egy társbetegségben és $50 \%$-uk legalább négy másik társbetegségben [48]. Emellett fontos kiemelni, hogy a COPD-ben szenvedő betegek egészségügyi ellátásának költségeit mintegy 4,7-szeresére emeli a többszörös komorbiditás jelenléte a társbetegség nélküli COPD-s csoport kezelési költségeihez képest [31].

A leggyakrabban előforduló társbetegségek a kardiovaszkuláris betegségek, diabétesz és metabolikus szindróma, kahexia, csontritkulás, anémia, reflux, fekélybetegségek és depresszió [32].

\section{A fogágybetegség és COPD kapcsolata}

A COPD és a fogágybetegség összefüggését számos tanulmány vizsgálta. Egy norvég tanulmány szerint a nagyon súlyos COPD-ben szenvedő, tüdőtranszplantáció előtt álló betegek esetén a parodontitisz prevalenciája megközelíti a 44\%-ot, szemben a nem COPD-s kontrollcsoport 7,3\%-os gyakoriságával [27]. 
Deo és munkatársai arra a következtetésre jutottak, hogy a minimum $20 \%$-os alveoláris csontveszteség következményeként $60 \%$-kal nő a COPD kialakulásának kockázata [7]. Wang és munkatársai következtetése szerint a COPD előfordulása és a szájhigiéné állapota direkt kapcsolatban állnak egymással [50]. Takeuchi és munkatársai bizonyították, hogy a parodontális betegség megjelenése hozzájárulhat a FEV1 jelentősebb csökkenéséhez, ami a COPD kifejlődésére utalhat [47]. A krónikus fogágybetegség és a COPD közötti lehetséges összefüggés felismerésének ellenére eddig kevés tanulmány foglalkozott azzal a kérdéssel, hogy a parodontális betegség kezelése javulást idéz-e elő a COPD-s rohamok előfordulásában, valamint a kezelt COPD hatással van-e a fogágy általános állapotára. Zhou $X$. és munkatársai egy előzetes tanulmányban arra a következtetésre jutottak, hogy a parodontális oki terápia csökkenti a COPD-s rohamok gyakoriságát és súlyosságát [52].

\section{Feltételezett patomechanizmus}

Mind a fogágybetegség, mind a COPD krónikus, gyakran évekig fennálló progresszív neutrofil jellegú gyulladásos állapotok [43], melyek a kötőszövet proteolítikus destrukcióját vonják maguk után [33]. Számos mechanizmus feltételezhető arra nézve, hogy a két betegség milyen befolyással lehet egymásra. A két leginkább elfogadott útvonal a patogén baktériumok belégzése, valamint a gyulladásos mediátorok és mikroorganizmusok hematogén terjedése a parodontális tasakfal fekélyein keresztül [28].

A szájüregben lévő patogén flóra belégzése légúti gyulladáshoz vezethet. Az orális mikroorganizmusok a légúti hám felszínének megváltoztatása révén elősegíthetik a légúti patogének adhézióját és kolonizációját, ezáltal hajlamosabbá téve azt az infekciókra. Mikro-aspirációk az egészséges emberben is gyakran megtörténnek, elsősorban alvás közben. Az egészséges emberek körében a normális saját védelmi mechanizmus gondoskodik arról, hogy a belélegzett kórokozók ne okozzanak a légúti hám felszínén eltéréseket [2]. Ezek a tisztulási folyamatok mind mechanikai, mind immunológiai folyamatok, melyek magukba foglalják a köhögést, valamint a kórokozók fagocitózisát is [12]. Ha a folyamatok hátterében valamilyen krónikus betegség is megfigyelhető, akkor az orális patogén baktériumok belégzése után a tisztulás valószínúsége kisebb lesz [39]. A károsodás jellemző a közepes és a súlyos dohányosokra, aminek az eredménye a szervezet fertőzésre való hajlamának fokozódása. Irodalmi adatok alapján kijelenthető, hogy a COPD akut fellángolásainak $70 \%$-áért egyes vírusok és/vagy baktériumok tehetők felelőssé [30]. A parodoncium baktérium-rezervoirként szolgálhat, mely másodlagosan fokozza a légutak kolonizációját és gyulladását. A COPD akut exacerbációja alatt a beteg állapotának elhúzódó, legalább két napja fokozódó rom- lását értjük, amely hirtelen kezdődik, és meghaladja a panaszok napi ingadozására jellemző minőséget [10]. A nem megfelelő szájhigiéné és a parodontális betegség összefüggésbe hozható a nozokomiális pneumoniával és feltételezhetően a lélegeztetéssel összefüggő tüdőgyulladás (ventillation associated pneumonia, VAP) megjelenésével is [6]. Egy metaanalízis szerint a fogágybetegségben szenvedők esetében intubálást követően nagy valószínűséggel alakult ki légúti megbetegedés [41]. Másik kutatócsoport metaanalízise arra a következtésre jutott, hogy az orális higiéne javítása és az orális antimikrobiális terápia szignifikánsan csökkenti a pneumoniára való hajlamot [41], így a direkt kapcsolat bizonyítottnak tekinthető. Ezek a pneumoniára hajlamosító szájüregi putatív baktériumok föleg gramnegatív baktériumtörzsek, melyek magukba foglalják az Aggregatibacter actinomycetemcomitanst agresszív fogágybetegségben és a Porphyromonas gingivalist, Treponema denticolát és Tanerella forsythiát krónikus fogágybetegségben [13]. Ám ezek a baktériumok nem hozhatók összefüggésbe alsó légúti fertőzésben szenvedő populációval (függetlenül a páciensek COPD státuszától), és jelenleg nincs olyan tanulmány, amely direkten bizonyítaná a COPD fellángolásai és az orális patogén baktériumok direkt kölcsönhatását. Egyes feltevések szerint a baktériumok belégzése nem szükséges ahhoz, hogy a két betegség kölcsönhatásba lépjen egymással [12].

A parodontitisz egy közismert, bizonyított dentális góc [34]. Három fô lehetséges haematogén útvonalat emel ki a szakirodalom a gócok által kifejtett hatás tekintetében: a metasztatikus fertózés, a metasztatikus károsítás, valamint a metasztatikus gyulladás útvonalát [38]. Metasztatikus fertőzésről akkor beszélünk, ha a parodontális tasakból időszakosan baktériumok ürülnek a véráramba és azzal távoli szövetekhez jutnak el. Étkezés és fogmosás során baktériumok kerülhetnek a véráramba, ami az akut fázis fehérjék fokozott képződéséhez vezethet [17]. A metasztatikus károsítás során a parodontális gócból bakteriális anyagcsere termékek, enzimek, endo- és exotoxinok kerülhetnek a véráramba, és azon keresztül jutnak el más szervekbe és szövetekbe. A szakirodalomban jelenleg nincs olyan kutatási eredmény, amely alá tudná támasztani ezen útvonal meglétét a COPD és parodontitisz kapcsolatában.

A metasztatikus gyulladás esetén a parodontális lézió következményeként az aktiválódott komplement rendszer faktorok és immunkomplexek (antigén-antitest komplexek) a véráram útján jutnak el távoli szervekbe, ahol a sejtek legyengülését, megbetegedését okozzák [11].

A parodontitisz sújtotta szövetekben már többféle gyulladásos citokint mutattak ki [40], melyek nagy részét sikerült azonosítani a véráramban [25] és a COPD-s betegek tüdőszekrétumában egyaránt [46]. A fogágybetegségben szenvedő betegek hiperreakciót (hiperreaktív monocyta makrofág fenotípus) mutatnak a ke- 
ringésben megjelenő baktériumok hatására, melynek következményeként fokozódik a reaktív oxidatív gyökök és proinflammatórikus citokinek felszabadulása [8]. A parodontális betegségben lokálisan felszabaduló citokinek a véráramba jutva távoli szervrendszereknél okozhatnak gyulladást.

A gyulladásos folyamatok esetén mind a parodontitisz kötőszöveti destrukciójában, mind pedig a COPD kialakulásában és akut fellángolásában is fontos szerepet játszanak a nagy számban megjelenő neutrophil granulocyták. A parodontitiszben szenvedő betegek véréből származó neutrofil granulocyták bakteriális ingerre hiperreaktivitást mutatnak. Ezek a fehérvérsejtek nagyobb mennyiségű reaktív oxigéngyököt és proinflammatórikus citokint szabadítanak fel, mint a nem túlműködő társaik. A neutrofil granulocyták lokalizált fogágybetegségben a fokozott működésük következményeként nagy menynyiségű gyulladásos citokint adnak le a keringési rendszerbe, melyek így a tüdő szöveteihez is eljuthatnak [16].

A COPD-s betegek keringésében cirkuláló neutrofil granulocyták sokkal érzékenyebben reagálnak a gyulladásos mediátorokra, mint az egészséges nem dohányzó egyénekben. A degranulációs folyamatokat csak súlyosbítja, ha az adott egyén a COPD mellett még dohányzik is. Ebből következik, hogy a dohányzó COPD-s betegek egészségügyi állapota gyorsabban romlik, mint a nem dohányzóké [27]. A neutrofil granulocyták képesek extracelluláris csapdákat létrehozni (neutrophil extracellular trap, NET). A NET bizonyos alkotóelemei szerepet játszanak az immunválasz generálásában [16]. Egyes parodontális baktériumok, mint a Porphyromonas gingivalis és a Fusobacterium nucleatum képesek a NET-et lebontani és a szisztémás keringésbe juttatni [16]. Ezek a bomlástermékek feltehetően a tüdő szöveteinek destrukciójában is részt vesznek [42]. A parodontitiszben a neutrofil granulocyták kemoattraktánsok irányába történő mozgási sebessége és pontossága rosszabb, mint a parodontális terápia után. Hasonló neutrofil mozgásmintázatokat lehet a COPD-s betegek esetében is felismerni [16].

A nyálban mérhető sziálsav koncentráció normál értéke $39,05 \mathrm{mg} / \mathrm{dl}$, mely krónikus parodontitisz esetén a $76 \mathrm{mg} / \mathrm{dl}$-t is elérheti. Abban az esetben, ha az egyén a fogágybetegség mellett COPD-ben is szenved, akkor a nyálban mérhető sziálsav koncentrációja közel 25\%kal nagyobb, mint gyulladásmentes fogágy esetén [15]. Elképzelhető, hogy a COPD és a parodontitisz közötti kapcsolatelemző kutatásokban ez a laboranalízis eljárás is elterjedhet [37].

\section{Megbeszélés}

A fogágybetegség és a COPD összefüggése jelenleg direkt módon nem bizonyított, ám egyre több tanulmány támasztja alá a két betegség közti összefüggés jelenlétét. Ha feltárásra kerül tényleges kapcsolat, akkor a COPD-ben és parodontitiszben szenvedő populáció te- rápiájának elmaradhatatlan alapkövét képezheti mindkét betegség komplex kezelése, így javítva a betegek állapotát és a két betegség jövőbeli prognózisát. Nagy szükség lenne olyan klinikai vizsgálatokra, melyekben nagy esetszámmal vizsgálnak parodontálisan érintett COPD-s betegeket, így megerősítve vagy cáfolva azt a feltevést, miszerint a fogágybetegek parodontális terápiája hozzájárulhat a COPD-ben szenvedő betegek életminőségének javításához [52].

\section{Rövidítések jegyzéke}

COPD: chronic obstructive pulmonary disease, krónikus obstruktív tüdőbetegség,

COVID-19: egy új koronavírus törzs által okozott megbetegedés

CPI-index: Community Periodontal Index

EU-13: $\quad$ Azok az országok, melyek 2004 után

csatlakoztak az Európai Unióhoz

FÁK: $\quad$ Független Államok Közössége

FEV1: erőltetett kilégzési másodperctérfogat

FVC: $\quad$ erőltetett kilégzési vitálkapacitás

NET: neutrophil extracellular trap, neutrofil granulocyták által létrehozott extracelluláris anyag

VAP: ventillation associated pneumonia, lélegeztetéssel összefüggő tüdőgyulladás

WHO: $\quad$ Egészségügyi Világszervezet

\section{Irodalom}

1. Alqahtani JS, et al: Prevalence, severity and mortality associated with COPD and smoking in patients with COVID-19: A rapid systematic review and meta-analysis. PLoS One 2020; 15 (5): e0233147. https://doi.org/10.1371/journal.pone.0233147

2. Bansal M, Khatri M, TANEJA V: Potential role of periodontal infection in respiratory diseases - a review. J Med Life 2013; 6 (3): 244-248.

3. Bingham CO, Moni M: Periodontal disease and rheumatoid arthritis: the evidence accumulates for complex pathobiologic interactions. Curr Opin Rheumatol 2013; 25 (3), 345-353. https://doi.org/10.1097/BOR.0b013e32835fb8ec

4. BOYLAN, et al: A prospective study of periodontal disease and risk of gastric and duodenal ulcer in male health professionals. Clin Trans Gastroenterol 2014; 5 (2): e49. https://doi.org/10.1038/ctg.2013.14

5. Böszörményı Nagy G, Balikó Z, Somfay A, Strausz J: Egészségügyi szakmai irányelv a krónikus obstruktív tüdőbetegség (chronic obstructive pulmonary disease - COPD) diagnosztikájáról és kezeléséről, az alap-, a szak- és a sürgősségi ellátás területén. Medicina Thoracalis 2014; 67: (Suppl.) 76-112.

6. Carvalho MA, et al: Oral condition of critical patients and its correlation with ventilator-associated pneumonia: a pilot study. Rev Odontol Unesp 2013; 42 (3): 182-187. https://doi.org/10.1590/S1807-25772013000300007

7. Deo V, Bhongade M, Ansari S, Chavan RS: Periodontitis as a potential risk factor for chronic obstructive pulmonary disease: A retrospective study. Indian J Dent Res 2009; 20: 466-470. https://doi.org/10.4103/0970-9290.59456

8. Dias IH, Matthews JB, Chapple IL, Wright HJ, Dunston CR, 
GRIFFITHS HR: Activation of the neutrophil respiratory burst by plasma from periodontitis patients is mediated by pro-inflammatory cytokines. J Clin Periodontol 2011; 38 (1): 1-7. https://doi.org/10.1111/j.1600-051X.2010.01628.x

9. Dietrich T, Sharma P, Walter C, Weston P, Beck J: The epidemiological evidence behind the association between periodontitis and incident atherosclerotic cardiovascular disease. J Periodontol 2013; 84 (4 Suppl): S70-S84. https://doi.org//10.1902/jop.2013.134008

10. Donaldson GC, Seemungal TA, Bhowmik A, Wedzicha JA: Relationship between exacerbation frequency and lung function decline in chronic obstructive pulmonary disease. Thorax 2002; 57 (10): 847-852. https://doi.org/10.1136/thorax.57.10.847

11. Fourrier F, Duvivier B, Boutigny H, Roussel-Delvallez M, CHOPIN C: Colonization of dental plaque: a source of nosocomial infections in intensive care unit patients.

Crit Care Med 1998; 26 (2): 301-308. https://doi.org/10.1097/00003246-199802000-00032

12. Gleeson K, EgGl DF, Maxwell SL: Quantitative aspiration during sleep in normal subjects. Chest 1997; 111 (5): 1266-1272. https://doi.org/10.1378/chest.111.5.1266

13. Haffajee AD, Socransky SS: Microbial etiological agents of destructive periodontal diseases. Periodontol 2000 1994; 5: 78-111. https://doi.org/10.1111/j.1600-0757.1994.tb00020.x

14. Hermann P, Gera I, Borbély J, Fejérdy $P$, Madléna M: Periodontal health of an adult population in Hungary: findings of a national survey. J Clin Periodontol 2009; 36: 449-457. https://doi.org/10.1111/j.1600-051X.2009.01395.x

15. Hernández-Cedillo A, García-Valdivieso MG, Hernández-Arteaga AC, Patiño-Marín N, Vértiz-Hernández ÁA, José-Yacamán M: Determination of sialic acid levels by using surface-enhanced Raman spectroscopy in periodontitis and gingivitis. Oral Dis 2019; 25 (6): 1627-1633. https://doi.org/10.1111/odi.13141

16. Hobbins S, Chapple IL, Sapey E, Stockley RA: Is periodontitis a comorbidity of COPD or can associations be explained by shared risk factors/behaviors? Int J Chron Obstruct Pulmon Dis 2017; 12: 1339-1339. https://doi.org/10.2147/COPD.S127802

17. Horani A, FERKOL TW: Advances in the genetics of primary ciliary dyskinesia: clinical implications. Chest 2018; 154 (3): 645. https://doi.org/10.1016/j.chest.2018.05.007

18. http://www.euro.who.int/_data/assets/pdf_file/0009/402777/ Tobacco-Trends-Report-ENG-WEB.pdf?ua=1 (2020.05.21.)

19. http://www.fokuszpont.dohanyzasvisszaszoritasa.hu/sites/ default/files/17_evnel_idosebb_lakossag_dohanyzas_ felmeres_II_honlapra_20 140128_v2.pdf (2020.05.21.)

20. http://www.fokuszpont.dohanyzasvisszaszoritasa.hu/sites/ default/files/17_evnel_idosebb_lakossag_dohanyzas_ felmeres_honlapra_2013 1009.pdf (2020.05.21.)

21. https://fokuszpont.dohanyzasvisszaszoritasa.hu/sites/default/ files/dohanyzas_visszaszoritas_hatteranyag_efi_20180506.pdf (2020.05.21.)

22. https://goldcopd.org/wp-content/uploads/2019/12/GOLD-2020FINAL-ver1.2-03Dec19_WMV.pdf (2020.05.21.)

23. https://www.google.com/url?sa=t\&rct=j\&q=\&esrc=s\&source= web\&cd=\&ved=2ahUKEwjSx6eNwsXpAhWiuXEKHczgB_IQ FjAAegQIBRAB\&url=https\%3A\%2F\%2Fkollegium.aeek.hu \%2FDownload\%2FDownload\%2F2253\&usg=AOvVaw2n rMk0hUjkeYw37xtPumJ (2020.05.21.)

24. https://www.who.int/news-room/fact-sheets/detail/the-top-10causes-of-death (2020.05.21.)

25. Karadag F, Karul ab, Cildag O, Yilmaz M, Ozcan H: Biomarkers of systemic inflammation in stable and exacerbation phases of COPD. Lung 2008; 186 (6): 403-409. https://doi.org/10.1371/ journal.pone.0158843

26. Kassebaum NJ, Bernabé E, Dahiya M, Bhandari B, Murray CJ, MARCENES W: 2014. Global burden of severe periodontitis in 1990-2010: a systematic review and meta-regression. J Dent Res 2014; 93 (11): 1045-1053. https://doi.org/10.1177/0022034514552491.
27. Leuckfeld I, Obregon-Whittle M, Lund MB, Geiran O, Buørtuft $\varnothing$, OLSEN I: Severe chronic obstructive pulmonary disease: association with marginal bone loss in periodontitis. Respir Med 2008; 102 (4): 488-494. https://doi.org/10.1016/j.rmed.2007.12.001

28. Linden GJ, Lyons A, Scannapieco FA: Periodontal systemic associations: review of the evidence. J Clin Periodontol 2013; 40 Suppl 14: 8-19. https://doi.org/10.1111/jcpe.12064

29. Lortet-Tieulent J, Soerjomataram I, López-Campos JL, Ancochea J, COEBERGH JW, SORIANO JB: International trends in COPD mortality, 1995-2017. Eur Respir J 2019; 54 (6): 1901791. https://doi.org/10.1183/13993003.01791-2019

30. MACKAY AJ, HURST JR: COPD exacerbations: causes, prevention, and treatment. Immunol Allergy Clin North Am 2013; 33 (1): 95-115. https://doi.org/10.1016/j.iac.2012.10.006

31. Mapel DW, Hurley JS, Frost FJ, Petersen HV, Picchi MA, CoULTAS DB: Health care utilization in chronic obstructive pulmonary disease: a case-control study in a health maintenance organization. Arch Intern Med 2000; 160 (17): 2653-2658. https://doi.org/10.1001/archinte.160.17.2653

32. Martinez CH, Mannino DM, Divo MJ: Defining COPD-Related Comorbidities, 2004-2014. Chronic Obstr Pulm Dis 2014; 1 (1): 51-63. https://doi.org/10.15326/jcopdf.1.1.2014.0119

33. Muthu J, Muthanandam S: Periodontitis and Respiratory Diseases: What Does the Recent Evidence Point to? Curr Oral Health Rep 2018; 5 (1): 63-69. https://doi.org/10.1007/s40496-018-0171-5

34. Newman HN: Focal infection. J Dent Res 1996; 75: 1912-1919. https://doi.org/10.1177/00220345960750120101

35. NovÁk T, és mtsai: Fogágybetegség kezelésének hatása a terhesség kimenetelére. Orv Hetil 2018; 159 (24): 978-984. https://doi.org/10.1556/650.2018.31103

36. PAGE RC, EKE PI: Case definitions for use in population-based surveillance of periodontitis. J Periodontol 2007; 78 Suppl 7: 1387-1399. https://doi.org/10.1902/jop.2007.060264

37. Palmer LJ, Chapple IlC, Wright HJ, Roberts A, Cooper PR: Extracellular deoxyribonuclease production by periodontal bacteria. J Periodontal Res 2012; 47 (4): 439-445. https://doi.org/10.1111/j.1600-0765.2011.01451.x

38. PÁRKÁNyI L, VÁlyI $P$, Nagy $K$, Fráter $M: A z$ odontogén góc és a szisztémás betegségek. Irodalmi áttekintés. Orv Hetil 2018; 159 (11): 415-422. https://doi.org/10.1556/650.2018.31008

39. Prasanna SJ: Causal relationship between periodontitis and chronic obstructive pulmonary disease.

$J$ Indian Soc Periodontol 2011; 15 (4): 359-365. https://doi.org/10.4103/0972-124X.92570

40. Preshaw PM, Taylor JJ: How has research into cytokine interactions and their role in driving immune responses impacted our understanding of periodontitis? J Clin Periodontol 2011; 38 Suppl 11: 60-84. https://doi.org/10.1111/j.1600-051X.2010.01671.x

41. Scannapieco FA, Bush RB, Paju S: Associations between periodontal disease and risk for nosocomial bacterial pneumonia and chronic obstructive pulmonary disease. A systematic review. Annals of Periodontology 2003; 8 (1): 54-69. https://doi.org/10.1902/annals.2003.8.1.54

42. SHEN TC, et al: Periodontal treatment reduces risk of adverse respiratory events in patients with chronic obstructive pulmonary disease: A propensity-matched cohort study. Medicine 2016; 95 (20): e3735. https://doi.org/10.1097/MD.0000000000003735

43. SHEN TC, et al: Risk of periodontal diseases in participants with chronic obstructive pulmonary disease: a nation-wide population based cohort study. Medicine 2015; 94 (46): e2047 https://doi.org/10.1097/MD.0000000000002047

44. Song Y, Klevak A, Manson JE, Buring JE, Liu S: Asthma, chronic obstructive pulmonary disease, and type 2 diabetes in the Women's Health Study. Diabetes Res Clin Pract 2010; 90 (3): 365-371. https://doi.org/10.1016/j.diabres.2010.09.010

45. Spiropoulou A, Lagiou O, Spiropoulos K, Lykouras D, Karkoulias K: Periodontitis and chronic obstructive pulmonary disease insights 
into various aspects of oral health. IntechOpen 2017 ; 61-67. https://doi.org/10.5772/intechopen.69957.

46. Stone H, McNab G, Wood AM, Stockley Ra, Sapey E: Variability of sputum inflammatory mediators in COPD and alpha1-antitrypsin deficiency. Eur Respir J 2012; 40 (3): 561-569. https://doi.org/10.1183/09031936.00162811

47. TAKEUCHI K, et al: Periodontal status and lung function decline in the community: the Hisayama Study. Sci Rep 2018; 8 (1): 13354. https://doi.org/10.1038/s41598-018-31610-3

48. VANFLETEREN LE, et al: Clusters of comorbidities based on validated objective measurements and systemic inflammation in patients with chronic obstructive pulmonary disease. Am J Respir Crit Care Med 2013; 187 (7): 728-735. https://doi.org/10.1164/rccm.201209-1665OC

49. VogeLMEIER, et al: Global strategy for the diagnosis, management, and prevention of chronic obstructive lung disease 2017 report:
GOLD executive summary. Eur Respir J 2017; 49: 1750214. https://doi.org/10.1183/13993003.50214-2017

50. WANG $Z$, et al: Periodontal health, oral health behaviours, and chronic obstructive pulmonary disease. J Clin Periodontol 2009; 36: 750-755. https://doi.org/10.23937/2469-5734/1510062

51. Zhong Y, SLade GD, Beck JD, Offendacher S: Gingival crevicular fluid interleukin-1beta, prostaglandin E2 and periodontal status in a community population. J Clin Periodontol 2007; 34 (4): 285-293. https://doi.org/10.1111/j.1600-051X.2007.01057.x

52. ZHou X, Han J, Liu Z, Song Y, Wang Z, Sun Z: Effects of periodontal treatment on lung function and exacerbation frequency in patients with chronic obstructive pulmonary disease and chronic periodontitis: A 2-year pilot randomized controlled trial. J Clin Periodontol 2014; 41: 564-572. https://doi.org/10.1111/jcpe.12247

The importance of the relationship between chronic periodontitis and chronic obstructive pulmonary disease Review of literature

Periodontitis is one of the most common human chronic inflammatory diseases and about $11 \%$ of adults develop its clinical signs. Untreated periodontitis ultimately leads to inflammation and destruction of the periodontium leading to the loss of the teeth. Periodontitis is considered as a dental focal infection. The foci can influence other diseases in different areas of the body through different pathways. Diseases and conditions such as cardiovascular disease, diabetes mellitus, rheumatoid arthritis, gastric ulcer, pregnancy complications and respiratory diseases such as aspiration pneumonia and chronic obstructive pulmonary disease (COPD) have been proven to be affected by the condition of the periodontium.

COPD is an inflammatory disease characterized by progressive deterioration of pulmonary function and increasing airway obstruction, including chronic bronchitis and emphysema. It has a worldwide prevalence in adults at the age of 40 years or older in about $9 \%-10 \%$, and it is currently the third leading cause of death worldwide. In addition, the incidence and mortality of COPD are continually increasing. An observational study found that $97 \%$ of a COPD cohort had at least one other comorbidity, with $50 \%$ having at least four. This impacts the health care costs of COPD patients with multiple comorbidities that are 4,7 times higher than those with no comorbidity.

As periodontitis and COPD are both chronic, progressive conditions characterized by neutrophilic inflammation with subsequent proteolytic destruction of connective tissue, it has been proposed that they share common pathophysiologic processes. Several mechanisms have been proposed to explain the association of periodontal disease and COPD. As summarized by the European Federation of Periodontology and American Academy of Periodontology (EFP/AAP), COPD inflammatory status may be modified either by aspiration of bacteria from the oral cavity and/or haematogenous dissemination of inflammatory mediators and plaque organisms from periodontal pockets. The present review of literature aims to investigate the potential connection between periodontal disease and COPD.

Keywords: chronic obstructive pulmonary disease, COPD, chronic periodontitis, focal infection, prevalence 